\title{
AGRICULTURAL INPUTS SUBSIDY IN NIGERIA: AN OVERVIEW OF THE GROWTH ENHANCEMENT SUPPORT SCHEME (GESS)
}

\author{
Amurtiya Michael ${ }^{1}$, Abdu Karniliyus Tashikalma ${ }^{1}$, David Chinda Maurice ${ }^{1}$ \\ ${ }^{1}$ Department of Agricultural Economics and Extension, Modibbo Adama University of Technology, Yola, \\ PMB 2076, Yola, Nigeria
}

\begin{abstract}
MICHAEL AMURTIYA, TASHIKALMA ABDU KARNILIYUS, MAURICE DAVID CHINDA. 2018. Agricultural Inputs Subsidy in Nigeria: an Overview of the Growth Enhancement Support Scheme (GESS). Acta Universitatis Agriculturae et Silviculturae Mendelianae Brunensis, 66(3): 781-789.

The Growth Enhancement Support Scheme (GESS) was initiated by the Nigerian government to boost agricultural production through the provision of 'smart subsidies' on some farm inputs to small-scale farmers. This review highlights the successes and challenges of the Scheme's implementation process across the country. The study reviewed scholarly articles and other secondary data from government sources on the scheme. Findings from the study revealed that the Scheme was able to deliver subsidised agricultural inputs to small-scale farmers with relative ease and at affordable rate which was able to boost farm output. However, the scheme is affected majorly by its politicization, the inability of the governments to release funds to agro-dealers leading to late delivery of inputs and the lack of support service (extension) to farmers. Based on these findings, it is therefore recommended that, adequate synergy should be established between all collaborating agencies of the government participating in the scheme to ensure adequate release of funds, timely disbursement of farm inputs and the provision of suitable support services to farmers.
\end{abstract}

Keywords: agricultural input, subsidy, growth enhancement support scheme, Nigeria

\section{INTRODUCTION}

Agriculture has always played a very prominent role in sustaining the economy of Nigeria. In fact, it was the mainstay of the nation's economy before the discovery of oil (petroleum). In, 2015, the agricultural sector contributed about $23 \%$ of the country's Gross Domestic Product, having approximately $75 \%$ share of non-oil exports earnings (Federal Ministry of Agriculture and Rural Development, 2016). Over the years, the sector has provided employment opportunities for the majority (over 70\%) of the nation's populace, especially those in rural areas (Ogbalubi and Wokocha, 2013). Due to the significance of this sector to the economic development of the country, the government was able to introduce and implement quite a lot of policies and programmes aimed at improving the sector and unleashing its potentials in the country (Nwaobiala and Ubor, 2016; Okunola, 2016). Over the years, some of these multifaceted programmes and projects include; the National Accelerated Food Production Programme (NAFPP), River Basin Development Authorities (RBDA), Operation Feed the Nation (OFN), Agricultural Credit Scheme (ACGS), Green Revolution (GR), Agricultural Development Programme (ADP), Directorate of Food, Roads and Rural Infrastructure (DFRRI), and the National Land Development Authority (NLDA) among others. In recent decades, the National Fadama Development Project, National Special Programme for Food Security, Community and Social Development Projects, and the Agricultural Transformation Agenda (ATA) were also implemented. These programmes and projects were implemented 
nationally to; increase land access through reforms, provide rural infrastructure, enhance credit access, and grant input subsidies and boost agricultural productivity.

However, despite these diverse interventions, the Nigerian agricultural sector is still under-developed. Mgbenka and Mbah (2016) attributed much of the failure of the agricultural development initiatives to different constraints that militate against smallholder farming in the country, which are mostly economic, political or financial. Other reasons for the decimal performance of the sector were elaborately outlined by Oyediran et al. (2014) to include gross under-investment in new technologies and infrastructures, slow adoption of existing improved technologies and constraints associated with the investment climate. Equally, Nwaobiala and Ubor (2016) and Obayelu (2016) were of the view that achieving any modern agricultural transformation and productivity in Nigeria depends among other things on the availability and adequacy inputs.

In recent years, there has been a resurgent interest in large-scale agricultural input subsidies across Sub-Saharan Africa (Dorward, 2009; Hansen and Baltzer, 2011; Abubakari and Abubakari, 2014; Dorward and Chirwa, 2014). Ellis (1992) gave the conventional argument for subsidies in agricultural development, which were to promote adoption of new technologies and thus increase agricultural productivity. As reported by Chibwana et al. (2012) in Mali and Aloyce et al. (2014) in Tanzania, access to subsidised farm inputs increases farmers' productivity significantly through increase in the farm size and reduced transition cost in the adoption of new technologies. Further, according to Seck (2016), input subsidy schemes appears to be associated with increased efficiency among farmers, and this tends to validate the argument that lower input prices, as a result of the subsidy, provide incentives for farmers to use more of the inputs, which in turn translates into increased output. These agricultural inputs range from improved seeds, fertilizers and crop protection chemicals to machinery, irrigation and knowledge (Hansen and Baltzer, 2011; Nwaobiala and Ubor, 2015).

In Nigeria, agricultural input subsidy occupies a central role in the policy tools of the government (Umar et al., 2015). According to Takeshima and Liverpool-Tasie (2013), fertilizer subsidy alone constituted nearly $68 \%$ of government agricultural expenditure in recent past. Agricultural inputs are a range of materials which may be used to make agricultural production possible, while input subsidies are grants given by the government to farmers in order to reduce their production cost and improve their profit margin. Over the years, the Nigerian government has been making considerable expenditure on the provision of subsidized farm inputs (especially fertilizer) in the country. As indicated in Tab. I, the direct costs of fertilizer subsidy per Metric Ton (MT) under the Market Stabilization Scheme (MSS) was 10,261 in, 2001 and has geometrically increased to 55,000 in, 2015 under the Growth Enhancement Support Scheme (GESS). Most recently, the Government earmarked over 27 billion to provide input subsidy to 1.5 million farmers in the $2016 / 2017$

I: Cost of Fertilizer Subsidy under Market Stabilization Scheme (MSS, 2001-2010) and Growth Enhancement Support Scheme (GESS, 2011-2015)

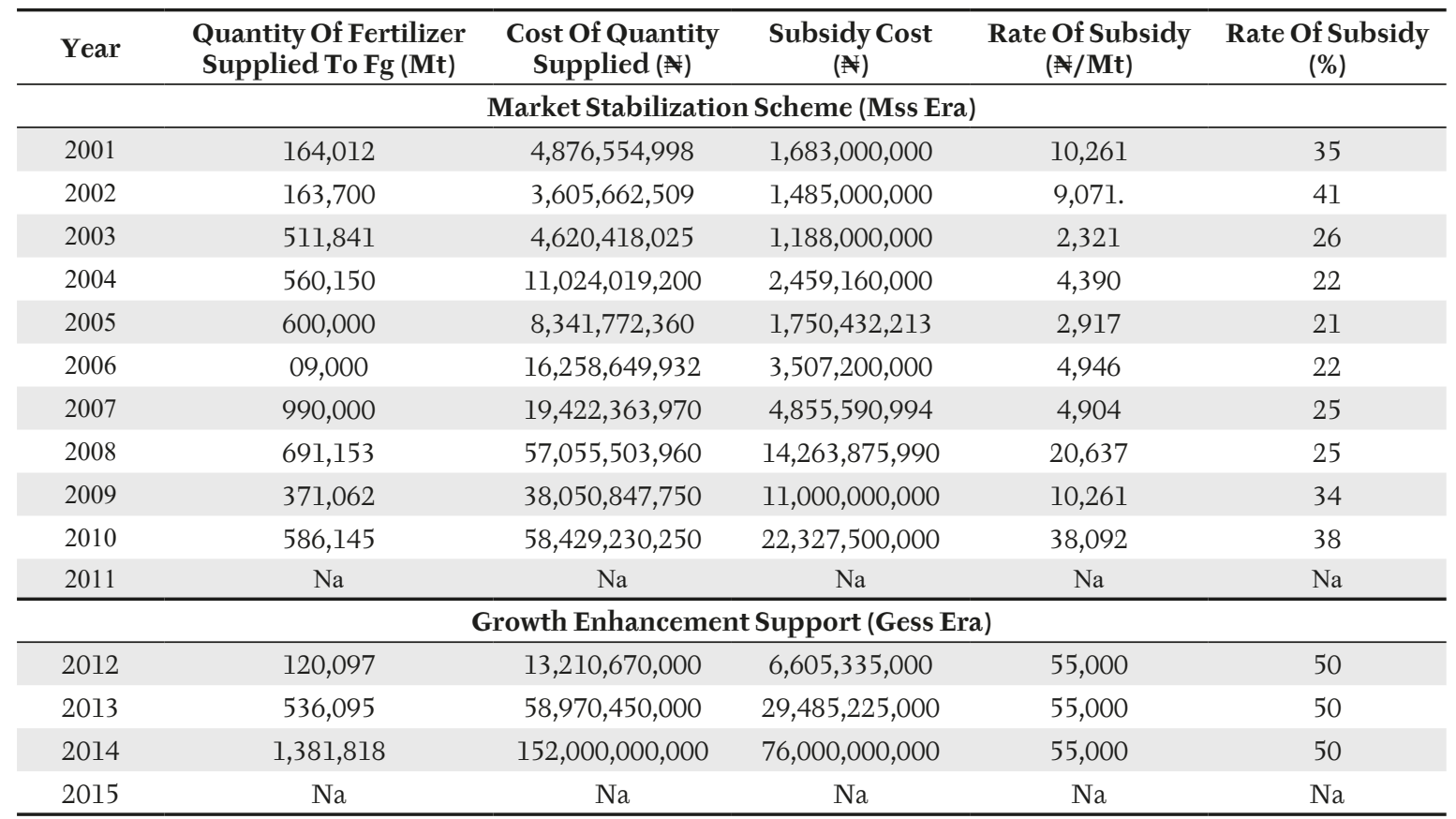

Source: Ayoola and Ayoola, 2016 
dry season farming input package. The cost of subsidy per farmer ranged between 22,125 to * 24, 825 depending on the type of crop the farmer cultivates (Federal Ministry of Agriculture and Rural Development, 2016). This bloated volume of agricultural input subsidy has mounted a huge fiscal burden on the Federal budget over time (Ayoola and Ayoola, 2016).

This huge financial burden (through input subsidies) raises concern about its sustainability considering the dwindling financial resources of the country. To Druilhe and Barreiro-hurlé (2012), the success of any subsidy scheme is highly dependent on implementation and sustainability. Subsidy programmes are sustainable if they can be maintained over the long term without draining the public resources, or if the outcomes in terms of wider adoption of agricultural inputs and improved agricultural productivity persist after their termination (Hansen and Baltzer, 2011).

Nigeria's past agricultural input subsidy policy (known as the Market Stabilization Scheme) was widely considered to have been ineffective owing to some obvious problems like massive diversion of supply to benefit the middlemen, the issue of elite capture, the cumbersome acquisition process, late delivery of inputs and the low quality of some of the inputs (Dorward, 2009; Grow Africa, 2016; Ayoola and Ayoola, 2016). The government has recently implemented an improved agricultural policy known as the Growth Enhancement Support Scheme (GESS) under the Agricultural Transformation Agenda (ATA). The primary objective of the scheme is to depoliticize the input sector by withdrawing the State from procurement of inputs and developing a private sector channel for input distribution (Grow Africa, 2016). It is an attempt in policy experimentation under a peculiar governance regime, characterized by programme accountability, participation, inclusiveness, transparency and due process of policy and the law governing the sector agricultural markets (Ayoola and Ayoola, 2016). Under the scheme, farm inputs like fertilizer, insecticides/herbicides, and improved seeds are disbursed to registered individual smallholder farmers through an electronic system (Tiri et al., 2015).

Achieving the set goals of the GES scheme requires having adequate and timely feedback from the farmers on the implementation process so far. This is because, sustainability of the Scheme and the success of other similar initiatives in the future is hinged on the attitudinal disposition of the targeted beneficiaries (Fadairo et al., 2015). Therefore, the broad objective of this review is to provide a better understanding of the entire GES Scheme. Specifically, the Scheme's achievements and challenges across the country over the years, and recommendations will be made on how the scheme can further be implemented more effectively and transform the nation's agriculture and the livelihood of the farmers.

\section{MATERIALS AND METHODS}

The study relied on published scholarly articles from journals, conference proceedings, annual reports of agro-based and other international organisations, newspaper articles, and secondary data from the Federal Ministry of Agriculture and Rural Development on the Growth Enhancement Support Scheme in Nigeria.

\section{RESULTS AND DISCUSSION}

\section{The Smart Subsidy}

The use of agricultural inputs is fundamental in modern agriculture while the provision of subsidies on inputs is an effective tool of bringing economic and social changes to a developing country (Lister,, 2011; Nwaobiala and Ubor, 2015; Food and Agriculture Organisation, 2015). Agricultural subsidies are monies given to farmers to support their operations. Subsidies may be provided directly, in the form of cash payments, or they may take the form of indirect support to address market failures and promote the adoption of new technologies (Fan et al., 2008). Smart subsidy is a new form of subsidy programs which is expected to improve access and use of farm inputs, increase agricultural production and productivity, and ultimately improve the wellbeing of farmers (Wiredu, 2015). The concept is based on the economic principles of efficiency, equity, and sustainability (Hansen and Baltzer, 2011). Hence, smart subsidy are subsidies provided to specific targets (beneficiaries) over a given period of time with measurable impacts and achievable goals. Smart subsidy instruments include vouchers, targeting, rationing, loan guarantees, demonstration packs and matching grants (Dorward and Chirwa, 2014) built-in to safeguard against fraud (Gregory,, 2006). So far, evidence from some East-African countries suggests that the smart subsidy initiatives have largely succeeded in increasing productivity, production, incomes, and food security (Wiredu, 2015).

Smart subsidies are expected to adhere to a number of its cardinal design principles which are, its pro-poor targeting, having marketbased solutions (based on demand and supply), the active participation of the private sector, and implemented within some defined period having a credible exit strategy to put a time limit on the support (Hansen and Baltzer, 2011; Minde et al., 2008; Tiba, 2009; Dorward, 2009; Chirwa and Dorward, 2013). A firm exit strategy helps control the costs of the initiative and promotes its sustainability. The subsidies are expected to reduce both affordability of inputs and profitability constraints of its targets (farmers). The inclusion of the private sector promotes efficiency in service delivery, especially farm inputs (Chirwa and Dorward, 2013). 


\section{The Growth Enhancement Support Scheme and its Prospects}

In a bid to revamp the agricultural sector and ensure food security, diversified economy and enhanced foreign exchange earnings, the Nigerian government implemented the Agricultural Transformation Agenda (ATA) programme (Federal Ministry of Agriculture and Rural Development, 2011, 2016). The central objectives of the programme are to boost agricultural output, encourage private-sector engagement, and create 3.5 million new jobs in the farming sector. Also, ATA aims to improve farmers' incomes through increased productivity, securing greater market access, and strengthening value chains (International Food Policy Research Institute (IFPRI, 2012). The agricultural transformation initiative has had a significant impact in some African countries e.g. Malawi where food production especially arable crops was greatly increased (Nwaobiala and Ubor, 2016). The Agricultural Transformation Agenda of the Nigerian government has four main critical components that include: the Nigeria IncentiveBased Risk-Sharing System for Agricultural Lending (NIRSAL) which aims to increase farmers' access to credit by de-risking agricultural financing by banks; the Staple crops processing zones which encourage different regions of the country to produce crops in which they enjoy a comparative advantage and to build commodity value chains around them; the Commodity-marketing corporations; and the Growth Enhancement Support Scheme (GESS) which seeks to boost agricultural productivity by providing subsidised inputs to farmers in a timely and efficient manner.

The Growth Enhancement Support Scheme (GESS) is a smart subsidy initiative which is aimed at remedying the shortcomings of the previous subsidy regimes. Hence, subsidies were moved from the State to genuine small-scale farmers directly, eliminating corruption and ensuring timely disbursement of farm inputs (Ojoko, 2014). Authenticity of the Scheme's beneficiaries is verified using their biometric data at the distribution centres. The objectives of the GES scheme were to; remove the usual complexities associated with farm input (especially fertilizer) distribution by extending inputs delivery notification via mobile phones to 20 million farmers in four years by targeting 5 million persons annually; encourage critical actors in the fertilizer value chain to work together to improve productivity, provide direct support to farmers to enable them to procure agricultural inputs at affordable prices, at the right time and place, and enhance farmers' income and promote food security (Oyediran et al., 2014; Alabi and Adams, 2015; Grow Africa, 2016; Nwaobiala and Ubor, 2016; Enemchukwu et al., 2017). GESS was introduced in May, 2012, as a pilot project in the 36 states of the country and the Federal Capital Territory. The scheme is also known as the e-wallet scheme. An e-wallet has thus been defined as an efficient and transparent electronic device system that makes use of vouchers for the purchase and distribution of agricultural inputs (Fadairo et al., 2015).

The successful implementation of the GESS scheme is hinged on the active participation of all its players (as shown in Fig. 1). These players include; the government (at both federal and state levels), commercial banks, fertilizer importers and key distributors, seed companies and agro-dealers, and the farmers (Motilewa et al., 2015).

The provision of subsidy is co-funded by both the Federal and State Governments (States contribute $25 \%$ of the subsidy cost). These governments pay input suppliers the difference between the discounted price and market price for each voucher they redeem. Similarly, the government will identify credible input suppliers and dealers and link them with financial institutions that will grant them funds based on the nature of their agreement. In essence, the Federal Government

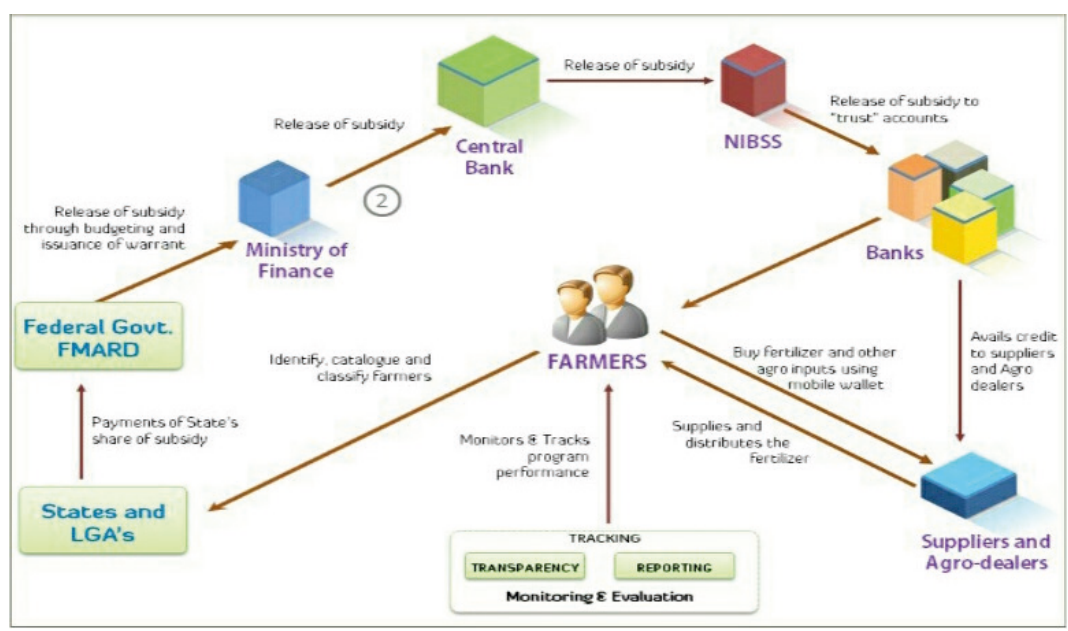

1: Stakeholders of the GES Scheme Source: Oredipe (2015) 
through the Federal Ministry of Finance is to guarantee on $70 \%$ of the credit provided by banks participating in the scheme. Furthermore, it is the sole prerogative of the government to register, screen and notify (when inputs are supplied) targeted beneficiaries through the Federal Ministry of Agriculture and Rural Development's local offices across the States of the federation. The role of the input suppliers/agro-dealers in the Scheme is to source for funds and acquire the recommended inputs and distribute them across redemption centres the country. The Federal Government will then reimburse the agro-dealers with its share of the subsidy cost after all the vetting process has been completed. The identities of the farmers are verified from the database of the National Identity Management Commission to eliminate the problem of multiple registrations by beneficiaries.

According to Fadairo et al. (2015) and Grow Africa (2016), the criteria for participation in the scheme is predicated on the farmer's socio-economic characteristics of age, farm size, and ownership of a phone. Beneficiaries must be adults by legal standard (not less than 18 years of age) and must have registered for the scheme at any of the centres across the country. Further, farmers must own a cell phone with a registered SIM card (to receive notice of input supply and redeem them from agro-dealers) and should be a small-scale farmer (with a landholding size of 3 hectares or less). The government subsidy is limited to only the following agricultural inputs; seeds of some selected crops (75\% subsidy in, 2017 rationed between $20-50 \mathrm{~kg}$ ), fertilizers (50\% subsidy on both organic and inorganic rationed between $50-100 \mathrm{~kg}$ ), micro-nutrients, insecticides, and herbicides (rationed at 2.5-4.5 litres, 2-3 litres and 2 litres respectively) (Nwaobiala and Ubor, 2016).

\section{Achievements of the Growth Enhancement Support Scheme}

Literature is replete with studies on the performance of the GES scheme at various times and parts of the country. The performance in this context has to do with the number of beneficiaries registered, quantities of inputs disbursed, the effect of improved input access on farmers' output and their satisfaction with the scheme. According to (Federal Ministry of Agriculture and Rural Development (2016) and Oredipe (2015), the scheme was able to register up to 14 million farmers and have disbursed 1.8 million Metric Tons of fertilizer and 174,000 Metric Tons of improved seeds to the farmers between, 2012 -, 2014. In assessing the effectiveness of the Scheme in early implementation stage, the Fertilizer Suppliers Association of Nigeria (2012) and the National Agricultural Extension and Research Liaison Services (2012) reported that farmers across the country were generally supportive of the scheme and considered it more effective in delivering subsidized inputs to them.
The performance of the scheme among farmers in some South-Eastern states of Anambra State and Abia State was assessed by Nwalieji et al. (2013) and Odoemelam and Maduka (2016). Findings from the studies showed that farmers had a high level of satisfaction on the scheme's implementation processes in the areas of registration and quantity of improved seed redeemed. The study further revealed that the Scheme made great changes in food productivity and farmers' access to farm inputs. Participation in the Scheme was influenced by the farmer's socio-economic characteristics of; age, farm size, educational level, farming experience, and frequency of extension contact. Similarly, in the same region in Imo State, the effect of the scheme on arable crop farmers' production was analysed by Nwaobiala and Ubor (2016). The result showed that the respondents perceived the scheme to be effective in enhancing the timely and increased disbursement of inputs. In terms of the respondents' farm output, farmers' mean farm output has increased from 1,626.67 kg (before joining the scheme) to $2,624.00 \mathrm{~kg}$ (before joining the scheme). This was attributed to increase in farm size due to the availability and quantity of inputs which has also lead to leading to increase in output and income among farmers. With reference to the farmers' income, Enemchukwu et al. (2017) evaluated the performance of the scheme among food crop farmers in Anambra State. The study revealed that farmers realized mean annual incomes of 433,974.87 and 717,796.48 before and after joining the scheme respectively. The implication of this finding is that the program made an appreciable impact on the annual income of the participant farmers.

Beneficiaries in both North-Central (Kwara State) and North-Western (Kaduna State) parts of the country have expressed satisfaction with the Scheme's implementation in the regions as revealed by Adebo (2014) and Umar et al. (2015) respectively. These studies revealed that majority of the respondents accessed subsidised farm inputs from the scheme and that has resuscitated their confidence in government programs. The level of satisfaction with the Scheme is influenced by age, extension visits, educational attainment, and farming experience. Similarly, the performance of the Scheme were evaluated in South-Western parts of the country. In Ijebu East Local Government Area of Ogun State, (Oyediran et al., 2015) examined the attitude of cocoa farmers towards the scheme. According to the result, the majority (over 70\%) of the respondents displayed low attitude to the GES scheme owing to some factors. In the same State, the attitude of crop farmers towards the scheme was assessed Fadairo et al. (2015). The result indicated that, farmers have a good attitudinal disposition towards the Scheme and that the Scheme has instilled farmers' interest in further agricultural programmes. 
On the overall performance of the scheme in the country, according to the International Fertilizer Development Centre (2013), over 4.5 million farmers were able to redeem fertilizer under the scheme in, 2013. At macro-level, the nation's food importation bill has declined by $403 \%$ (due to increased farm output), and the number of jobs in the agriculture sector also increased by 3.56 million between, 2012 and, 2014 inputs through vouchers being sent to farmers (Adesiri, 2015).

\section{Challenges of the Growth Enhancement Support Scheme}

Despite the appreciable progress recorded in the implementation of the GES scheme, there are still some challenges limiting the scheme from achieving its set objectives in totality. These challenges are associated with all the key actors of the scheme, especially, the federal/state government, agro-dealers and the farmers. Oredipe (2015) viewed the dominance of the federal government at the expense of implementation and ownership of State and Local Government structures as an issue that may affect the success of the scheme. For instance, due to this coordination problems, Imo and Zamfara States (in, 2013) pulled out of the scheme and the farmers in that state enjoyed only subsidy provision made by the federal government. The States had some reservations about the technology being used then which to them had created room for some irregularities. Further, there was no implementation of the Scheme completely in, 2015 owing to some political reasons, especially the emergence of a new government regime (Ayoola and Ayoola, 2016). There is also the issue of the Government's inability to start every stage of the scheme's implementation uniformly across the country. For instance, only some selected States were able to launch the Scheme for, 2016 as at August 6th that year (Adewale, 2016).

The inability of the government to release funds to agro-dealers in good time has resulted in late or even none-delivery of inputs in some cases. This has implications for the input suppliers who supplied products on credit (Fertilizer Suppliers Association of Nigeria, 2012). Studies have shown that late delivery of inputs is a major challenge to the successful implementation of the scheme across the country (Federal Ministry of Agriculture and Rural Development, 2016; Nwaobiala and Ubor, 2015; Oyediran et al., 2015; Fertilizer Suppliers Association of Nigeria, 2012). This is because most agricultural activities are seasonal in nature, hence, the need for timely delivery and disbursement of inputs. But, this can only be achieved if all parties involved in the provision of this subsidy were able to keep their side of the bargain.

For effectiveness, farmers' data are expected to be uploaded completely at redemption centres. Oyediran et al. (2014) reported the problem of uploading incomplete farmers' data which complicates the process of redeeming vouchers.
This leads to the use of paper voucher which is expensive and time-consuming for agro-dealers and the government to process (Promoting Pro-Poor Opportunities in Commodity and Service Markets, 2014) and may create room for corruption (Grow Africa, 2016). This has serious implication on the performance of the agro-dealer and in turn the farmers. Further, the low-density coverage of agro-dealers in the country is another impediment causing farmers to travel relatively long distance at a cost to redeem inputs (Adebo, 2014). In some redemption centres, the inadequacy of manpower and non-commitment of some of the staff has affected the efficiency of the scheme (Nwaobiala and Ubor, 2015; Oyediran et al., 2015; Fadairo et al., 2015).

Low education and ICT skills among most Nigerian farmers has affected the smooth implementation of the scheme (Motilewa et al., 2015). This is because, ownership of a mobile phone is not common to all rural areas in the country owing to cost of acquiring the facility, ease of operating the device and scope of service provision by telecommunication service providers (Oyediran et al., 2015; Nwalieji et al., 2013). Similarly, in areas where there is telecommunication service reach, service delivery is hampered by poor networks which affect the ability of farmers to benefit from the Scheme (Nwaobiala and Ubor, 2015; Oyediran et al., 2015; Alabi and Adams, 2015; Fertilizer Suppliers Association of Nigeria, 2012). Further, the successful implementation of any public policy or scheme is hinged on the adequacy of information provided to its targeted constituents. In case of the GES scheme, there was inadequate awareness created to educate farmers on the Scheme's implementation process and this has affected their participation in the scheme (Oyediran et al., 2015; National Agricultural Extension and Research Liaison Services, 2012; Nwalieji et al., 2013; Adebo, 2014).

Contrary to expectations, the Scheme has shown trappings of elite capture in some locations due to the interference of influential people in the operation of the Scheme (Fadairo et al., 2015; Alabi and Adams, 2015). In some cases, even rightful beneficiaries were excluded from the Scheme (Federal Ministry of Agriculture and Rural Development, 2016). Equally, competition between suppliers of the GES scheme is subdued because the Federal Government has granted regional monopolies to certain suppliers (Promoting Pro-Poor Opportunities in Commodity and Service Markets, 2014).This has a very negative influence on the disposition of the farmers towards the scheme and may affect other future innovations of this nature. Even though the Scheme was meant to benefit small-scale farmers, the quantity of inputs being disbursed is considered grossly inadequate to meet their needs (Fertilizer Suppliers Association of Nigeria, 2012; National Agricultural Extension and Research Liaison Services, 2012). In other instances, the types of input supplied were inappropriate to the locations while in some 
cases the inputs delivered may be sub-standard or counterfeit (Federal Ministry of Agriculture and Rural Development, 2016; Fertilizer Suppliers Association of Nigeria, 2012). This can be attributed to the inflexibility of the scheme in adopting a one-size-fits-all approach in providing inputs to farmers (Motilewa et al., 2015). Oxford Business Group (2016) argued that, while scheme has brought certain level of improvements in farm outputs, it has failed to transform productivity in most instances. This was attributed to the engagement of many inexperienced agro-dealers who lack formal training on the products they sell and are unable to provide effective extension services to their customers. This has underscored the relevance of agricultural extension in enhancing productivity among farmers.

In recent years, the Nigerian economy has faced recession which has affected the capacity of governments to fund programmes like the GESS. According to Federal Ministry of Agriculture and Rural Development (2016), the government is still heavily indebted to input suppliers for inputs they supplied in the past. This has a serious implication on the effectiveness and sustenance of the Scheme for its planned duration since such debts have to be settled and other funds will still be sourced for future implementation.

\section{CONCLUSION}

Most farmers across the country were optimistic about the potentials of the GES scheme in efficiently delivering subsidised farm inputs to them. However, the implementation of the Scheme and its sustainability is affected by certain factors and may limit the scheme's ability to achieve its set objectives. Hence, the need for the challenges of the Scheme to be addressed and the Scheme be sustained continuously by all the stakeholders. Therefore, the following recommendations are made to ensure that all the objectives set for the Scheme were achieved;

There is the need to integrate other complementary policies and programmes (especially the provision of rural infrastructure, access to financial services and adequate extension services) for beneficiaries to get the best out of the Scheme.

Extensive sensitization using local channels and languages willimprove the effectiveness of the scheme and reach more beneficiaries. Also, the government should ensure that telecommunication service providers have improved the scope and quality of their services to reach the farmers who mostly reside in rural areas.

There is a need for synergy between all collaborating agencies of the government who play a critical role in the scheme's implementation. Similarly, the government should ensure that farmers' records are updated at regular intervals to discourage the use of paper voucher which has many limitations. Redemption centres should be manned by adequate and committed staff to make the entire redemption process easy for the beneficiaries and enhance input delivery and effectiveness of the system.

It is very important for inputs to be delivered in good time for the beneficiaries. Similarly, input supplied should be of good quality and appropriate to the local context and the quantity rationed to farmers be increased.

The government should ensure the sustainability of the scheme by playing its specified roles as obligated, especially in the areas of timely subsidy payments to agro-dealers.

8. Acknowledgment

The authors sincerely appreciate the staff of Federal Department of Agriculture Yola for their assistance in supplying the necessary in formation for the study.

\section{REFERENCES}

Abubakari, F. and Abubakari, F. 2014. Effects of Awareness of Fertilizer Subsidy on the Yield of Crops among Rural Farmers in Ghana. International Journal of Agricultural Science, Research and Technology in Extension and Education Systems (IJASRT in EESs), 4(3): 123-126.

Adebo, G. M. 2014. Effectiveness of E-Wallet Practice in Grassroots Agricultural Services Delivery in Nigeria - A Case Study of Kwara State Growth Enhancement Support Scheme. Journal of Experimental Biology and Agricultural Sciences, 2(2320): 410-418.

Adewale, K. 2016. Six States to Kick Off 2016 Growth Enhancement Scheme. ThisDay. Available at: www. thisdaylive.com/index.php/2016/08/06 [Accessed: 2017, December 15].

Alabi, R. A. and Adams, O. O., 2015. The Pro-Poorness of Fertilizer Subsidy and its Implications on Food Security in Nigeria. Work in Progress (WIP) Report Submitted to African Economic Research Consortium, Nairobi, Kenya.

Aloyce, G. M., Gabagambi, D. M. and Hella, J. P. 2014. National Agricultural Input Voucher Scheme Impact on Productivity and Food Security of Smallholder Farmers in Tanzania. Journal of Economics and Sustainable Development, 5(21): 32-43.

Ayoola, G. and Ayoola, J. S. 2016. Thetransformation of smallholderagriculture in Africa:lessons in policy experimentation and governance from Nigeria. Addis Ababa, Ethiopia. 
Chibwana, C., Fisher, M. and Shively, G. 2012. Cropland Allocation Effects of Agricultural Input Subsidies in Malawi. World Development, 40(1): 124-133.

Chirwa, E. and Dorward, A. 2013. The role of the private sector in the Farm Input Subsidy Programme in Malawi. Available at: http://www.future-agricultures.org/publications/research-and-analysis/1743the-role-of-the-private-sector-in-the-farm-input-subsidy-programme-inmalawi/file [Accessed: 2017, December 15].

Dorward, A. 2009. Rethinking Agricultural Input Subsidy Programmes in A Changing World. London, UK: School of Oriental and African Studies, University of London.

Dorward, A. and Chirwa, E. 2014. The rehabilitation of agricultural input subsidies? London, UK. London, UK: School of Oriental and African Studies, University of London.

Druilhe, Z. and Barreiro-hurlé, J. 2012. Fertilizer subsidies in sub-Saharan Africa. FAO ESA working paper No 12-04. Rome, Italy: FAO.

Ellis, F. 1992. Agricultural policies in developing countries. Cambridge, UK: Cambridge University Press.

Enemchukwu, D. C., Ugwumba, C. O. A. and Okeke, Uche. 2017. Performance of the Growth Enhancement Support Scheme (G.E.S.S.) Among Food Crop Farmers in Anambra State, Nigeria. International Journal of Multidisciplinary Research and Analysis, 1(1): 13-22.

Fadairo, O. S., Olutegbe, N. S. and Tijani, A. M. 2015. Attitude of crop farmers towards e-wallet platform of the Growth Enhancement Support Scheme for input delivery in Oke-Ogun area of Oyo state. Journal of Agricultural Informatics, 6(2): 62-71.

Fan, S., Ashok, G. and Sukhaseo, T. 2008. Investment, Subsidies and Pro-poor growth in Rural India. Agricultural Economic, 39(2): 163-170.

Federal Ministry of Agriculture and Rural Development. 2016. The Agriculture Promotion Policy (2016-2020). Abuja, Nigeria: FMARD.

Federal Ministry of Agriculture and Rural Development. 2011. Agricultural Transformation Blue Print. Abuja, Nigeria: FMARD.

Fertilizer Suppliers Association of Nigeria. 2012. The Growth Enhancement Support Scheme (GESS) Monitoring Report 2012. Abuja, Nigeria: FSAN

Food and Agriculture Organisation. 2015. Regional Overview of Food Insecurity. Accra, Ghana: FAO.

Gregory, I. 2006. The Role of Input Vouchers in Pro-Poor Growth. Selected background paper Prepared for the African Fertilizer Summit June 9-13, 2006 Abuja, Nigeria.

Grow Africa. 2016. Fertilizer Subsidy Reform Revives Nigeria's Agriculture. Abuja, Nigeria: Grow Africa.

BALTZER, K. T. and HANSEN, H. 2011. Agricultural input subsidies in Sub-Saharan Africa. Copenhagen, Denmark: Ministry of Foreign Affairs.

International Food Policy Research Institute (IFPRI). 2012. IFPRI-Africa Lead report on Assessment of Nigeria's Agriculture Transformation Agenda(ATA) and Capacity Building Needs. USAID.gov. Available at: http://pdf.usaid. gov/pdf_docs/PA00K1SH.pdf [Accessed: 2017, December 15].

International Fertilizer Development Centre. 2013. Nigeria Sets Stage for Agricultural Revolution. Available at: www.ifdc.org [Accessed: 2017, December 15].

International Monetary Fund. 2015. Issues Paper on Nigeria. Washington, D.C.: IMF.

Kayode, K. 2013. Political Economy of Fertilizer Subsidy Implementation Process in Nigeria. Policy Brief, (December), pp.1-4.

Leke Adesiri. 2015. Agriculture: Buhari needs to sustain Adesina's legacies. Vanguard. Available at: http://www. vanguardngr.com/2015/06/agriculture-buhari-needs-to-sustain-adesinas-legacies/ [Accessed: 2017, December 15].

Lister, N. M. 2011. Agricultural Subsidies, Productivity and Rural Assets: The effect of Farmer Input Support Programme (FISP) on small scale farmers in Mwembeshi-Chibombo District of Zambia. Unpublished Master degree programme in Arts and Development Studies, presented to Graduate School of Development Studies, International Institute of Social, Studies, Hague Netherlands.

Mgbenka, R. N. and Mbah, E. N. 2016. A Review of Smallholder Farming in Nigeria: Need for Transformation. International Journal of Agricultural Extension and Rural Development Studies, 3(2): 43-54.

Minde, I., Jayne, T.S. Crawford, E., Ariga, J and Govereh, J. 2008. Promoting Fertilizer Use in Africa: Current Issues and Empirical Evidence from Malawi, Zambia, and Kenya. ReSAKSS Working Paper No. 13. ReSAKSS.

Minot, N. and Benson, T. 2009. Fertilizer Subsidies in Africa; Are Vouchers the Answer? Issue briefs from International Food Policy Research Institute (IFPRI), No. 60.

Motilewa, B. D., Worlu, R. E. K., Adepoju, Y. and Fayomi, O. O. 2015. Interrogating the Citizen-Centered Services and Development in Nigeria's Agricultural Sector Through E-Governance. Presented at Covenant University Conference on Egovernance in Nigeria.

National Agricultural Extension and Research Liaison Services. 2012. National Report of Agricultural Performance Survey of 2012 Wet Season in Nigeria. Zaria, Nigeria.

Nwalieji, H. U., Uzuegbunam, C. O. and Okeke, M. N. 2013. Assessment of Growth Enhancement Support Scheme among Rice Farmers in Anambra State, Nigeria. Journal of Agricultural Extension, 19(2): 71-81. 
Nwaobiala, C. U. 2015. Strengthening Agricultural Extension Delivery through Institutional Approach in Nigeria. In: Nwachukwu, I., Onumadu, F. N,, Ifenkwe, G. E., Agbarevo, M. B. N., Akpu, U., Odoemelam, L. E and Nwaobiala, C. U. (Eds.). Contemporary Issues in Extension Systems and Development, pp. 38-45.

Nwaobiala, C. U. and Ubor, V. U. 2016. Effectiveness of Electronic Wallet System of Growth Enhancement Support Scheme Distribution among Arable Crop Farmers in Imo State, South Eastern Nigeria. Scientific Papers Series Management, Economic Engineering in Agriculture and Rural Development, 16(1): 355-360.

Obayelu, A. E. 2016. Cross-Country Comparison of Voucher-Based Input Schemes in Sub-Sahara Africa Agricultural Transformation: Lessons Learned and Policy Implications. Agriculturae Conspectus Scientificus, 81(4): 251-267.

Odoemelam, L. E. and Maduka, O. A., 2016. Participation of Farmers towards Growth Enhancement Support Scheme and its Effect on Crop Performance in Abia State, Nigeria. International Journal of Trend in Research and Development, 3(4): 69-72.

Ogbalubi,L.Nand Wokocha,C.C.2013.Agricultural Development and Emplyoment Generation:The Nigeria Experience. IOSR Journal of Agriculture and Veterinary Science (IOSR-JAVS), 2(2): 60-69.

Ojoko, E. 2014. Growth Enhancement Support Scheme (GESS) and the Challenges of Food Security in Nigeria: A Review. Journal of Agricultural and Biological Sciences, 9(7): 226-232.

Okunola, A. M. 2016. Role of Legislature in Sustainable Agricultural Development in Developing Nations: A Case Study of Nigeria. Turkish Journal of Agriculture - Food Science and Technology, 4(5): 330-335.

Oredipe, A., 2015. Sustaining the Positive Outcome of The Agricultural for Attaining Competitiveness, Sustainability \& Inclusive Growth. In: $21^{\text {st }}$ Nigerian Economic Summit. Lagos, Nigeria, pp. 15-30.

Oyediran, W. O. 2014. Attitude of Cocoa Farmers to Growth Enhancement Support Scheme (GES) in Ijebu East Local Government Area of Ogun State, Nigeria. World Journal of Biology and Medical Sciences, 1(3): 108-117.

Oyediran, W. O., Dick, T. T., Owolade, E. O., and Oluade, E. A. 2015. Contributions of Growth Enhancement Support Scheme (GESS) programme to food security and poverty alleviation of Agricultural Cooperatives in Ogun State , Nigeria. Journal of Educational Policy and Entrepreneurial Research (JEPER), 2(June): 13-22.

Oxford Business Group. 2016. State efforts to boost agricultural output in Nigeria. Oxford Business Group. Available at: http://www.oxfordbusinessgroup.com/overview/state-efforts-boost-agricultural-outputnigeria [Accessed: 2017, December 15].

Propcom Mai-karfi. 2014. Education and Lasting Access to Fertilizer: How Nigerian Smallholders and Businesses are Prospering Together. A Propcom Mai-karfi case study. Abuja, Nigeria.

Takeshima, H. and Liverpool-Tasie, L. S. 2013. Fertilizer subsidy, political influence and local food prices in sub-Saharan Africa: Evidence from Nigeria. In: Agricultural $\sigma$ Applied Economics Association'sm2013 AAEA $\sigma^{\circ}$ CAES Joint Annual Meeting. Washington DC, USA, 1-38.

Tiba, Z., 2009. The role of input subsidies: Operational guidelines on implementation Policies for Good Economic Management of Food Price Swings in African Countries. Rome, Italy.

Tiri, G. D., Ojoko, E. A. and Aruwayo, A. 2015. Growth Enhancement Support Scheme (GESS) and the Challenges of Food Security in Nigeria: A Review. ARPN Journal of Agricultural and Biological Science, 9(7): 226-232.

Seck, A. 2016. Fertilizer Subsidy and Agricultural Productivity in Senegal. AGRODEP Working Paper 0024, pp. 2-31.

Umar, S., Oteikwu, O. P., Shuaibu, H., Duniya, K. P. and Tambari, I. W., 2015. Factors Influencing Level of Satisfaction with Growth Enhancement Support Scheme among Farm Families in Kaduna State, Nigeria. Journal of Agricultural Extension, 19(1): 10-21.

Wiredu, A. N. 2015. Impacts of Fertilizer Subsidy on Farm-Level Productivity And Food Security: A Case Study of Rice-Producing Households in Northern Ghana. An unpublised PhD thesis submited to the Institute of Agricultural Economics and Social Sciences in the Tropics and Subtropics University of Hohenheim. 